Ukrainian]

5. Marychevskyi, M. (2005). Alexander Archipenko: Vision and continuity (p.p. 38-41). Kyiv: Fine Art № 3. [in Ukrainian].

6. Valter R. Martin (1973). Mykhailo Urban: catalog of works. Chicago: Ukrainian Institute of Modern Art. [in Art. [in Ukrainian].

8. Novozhenets, H. (2015). Fine art of Ukrainian Diaspora of 1940-1970 years: multivariate artistic experience. Lviv: Kalvariia. [in Ukrainian].

9. Pevnyi, B. (2005). Masters of our art. Kyiv: Suchasnist. [in Ukrainian].

10. Protas, M. (2006). Ukrainian sculpture of the XX century. Kyiv: Intertekhnolohiia. [in Ukrainian].

11. Yatsiv, R. (2014). Ron Kostyniuk. Colorform Odyssey: catalog. Lviv: National Museum in Lviv named after Andrey Sheptytsky. [in Ukrainian].

12. Berehovska, Kh. (2015) Sviatoslav Hordynskyi about art: collection of articles. Lviv: Apriori. [in Ukrainian].

13. Mysiuha, B. (2001). Sculpture by Mykhailo Dzyndra. Ivano-Frankivsk: Lileya-NV. [in Ukrainian].

14. Stelmashchuk, H. (2013). Ukrainian artists in the world. Materials to the History of Ukrainian Art of the XX Century. Lviv: Apriori, Lviv National Academy of Arts (S.-r. Sector). [in Ukrainian].

15. Fedoruk, O. (1996). Aka Pereima's Wonderland. Kyiv: Veselka. [in Ukrainian].

16. Fedoruk, O. (2008). Ukrainian cultural studies. History and theory of art. Figures. Folklore. Reviews: Book 3. Kyiv: Intertekhnolohiia. [in Ukrainian].

17. Archipenko, A. (1960). Archipenko: Fifty Creative Years, 1908-1958. New York : TEKHNE. [in English].

Стаття надійшла до редакції 16.06.2019 p.

УдК УДК 793. 38 (4-11) «18»

Павлюк Тетяна Сергіївна

кандидат мистецтвознавства,доцент, Київський національний університет

культури і мистецтв,

ORCID 0000-0002-3940-9159

24caratsofart@gmail.com

\title{
ФОРМУВАННЯ СТАНДАРТНОЇ ТА ЛАТИНОАМЕРИКАНСЬКОЇ ПРОГРАМ У СИСТЕМІ КОНКУРСНОГО БАЛЬНОГО ТАНЦЮ В НІМЕЧЧИНІ
}

\begin{abstract}
Мета статті - виявити особливості еволюціонування стандартної та латиноамериканської програм конкурсного бального танцю в Німеччині (1910-1970-ті рр.); визначити специфіку трансформаційних процесів професійної діяльності німецьких вчителів танців на початку XX ст. у контексті становлення єдиного танцювального стилю. Методологія дослідження. Застосовано системний підхід до вивчення специфіки формування стандартної та латиноамериканської програм конкурсного бального танцю. Для здійснення мети використано комплексні методи дослідження: історико-культурний (для розгляду історичної динаміки розвитку професії вчителя танців); історично-порівняльний (для вивчення процесу формування єдиного танцювального стилю представниками Англії, Франції та Німеччини); типологічний (для виявлення факторів впливу на процеси розробки та канонізації конкурсного бального танцю); системний (для вивчення зв'язків простору танцювального мистецтва); компаративний (для порівняння структурних елементів танців), а також метод теоретичного узагальнення (для підведення підсумків дослідження). Наукова новизна. Вперше в історії вітчизняного мистецтвознавства розглянуто та проаналізовано діяльність конгресу Міжнародної організації вчителів танців у Відні (1911р.) та виявлено вплив німецьких вчителів на фрормування єдиного танцювального стилю в системі конкурсного бального танцю. Розглянуто навчальну програму затверджену Асоціацією німецьких вчителів танців в якості апробації рішень Віденського конгресу. Досліджено специфіку формування європейської та латиноамериканської програм в системі конкурсного бального танцю в Німеччині та виявлено вплив німецьких танцюристів на розробку і канонізацію нових версій бальних танців. Висновки. Внаслідок активізації професійної та організаційної діяльності вчителів танців за ініціативи німецьких танцювальних об'єднань на початку 1910-х рр., було затверджено рішення про доцільність формування єдиного танцювального стилю в системі конкурсного бального танцю на міжнародному рівні. Дослідження особливостей проведення регіональних змагань та національних чемпіонатів бальних танців у Німеччині в 1910-1970-ті pp. засвідчує специфіку процесу становлення в країні стандартної та латиноамериканської програм. Значний вплив на популяризацію в Німеччині латиноамериканських танців мали показові виступи французьких танцюристів. Розроблені німецькими танцюристами варіанти бальних танців - «Віденський вальс» (П. Кребс) та «Танго» (Ф. Кемп) лишаються традиційними в європейській програмі й на сучасному етапі.
\end{abstract}

Ключові слова: конкурсний бальний танець, Німеччина, вчителі танців, стандарт, латиноамериканська програма.

Павлюк Татьяна Сергеевна, кандидат искусствоведения, Киевский национальный университет культуры и искусств

Формирование стандартной и латиноамериканской программ в системе конкурсного бального танца в Германии

(C) Павлюк Т. С., 2019 
Цель статьи - выявить особенности эволюционирования стандартной и латиноамериканской программ конкурсного бального танца в Германии (1910-1970-е гг.); определить специфику трансформационных процессов профессиональной деятельности немецких учителей танцев в начале XX в. в контексте становления единого танцевального стиля. Методология исследования. Применен системный подход к изучению специфики формирования стандартной и латиноамериканской программ конкурсного бального танца. Для осуществления цели использовано комплексные методы исследования: историко-культурный (для рассмотрения исторической динамики развития профессии учителя танцев); историко-сравнительный (для изучения процесса фрормирования единого танцевального стиля представителями Англии, Франции и Германии); типологический (для выявления факторов влияния на процессы разработки и канонизации конкурсного бального танца); системный (для изучения связей пространства танцевального искусства); компаративный (для сравнения структурных элементов танцев), а также метод теоретического обобщения (для подведения итогов исследования). Научная новизна. Впервые в истории отечественного искусствоведения рассмотрена и проанализирована деятельность конгресса Международной организации учителей танцев в Вене (1911 г.) и выявлено влияние немецких учителей на формирование единого танцевального стиля в системе конкурсного бального танца. Рассмотрено учебную программу утвержденную Ассоциацией немецких учителей танцев в качестве апробации решений Венского конгресса. Исследована специфика формирования европейской и латиноамериканской программ в системе конкурсного бального танца в Германии и выявлено влияние немецких танцоров на разработку и канонизацию новых версий бальных танцев. Выводы. Вследствие активизации профессиональной и организационной деятельности учителей танцев по инициативе немецких танцевальных объединений в начале 1910-х гг., было принято решение о целесообразности формирования единого танцевального стиля в системе конкурсного бального танца на международном уровне. Исследование особенностей проведения региональных соревнований и национальных чемпионатов бальных танцев в Германии в 1910-1970-е гг. свидетельствует о специфике процесса становления в стране стандартной и латиноамериканской программ. Значительное влияние на популяризацию в Германии латиноамериканских танцев имели показательные выступления французских танцоров. Разработанные немецкими танцорами варианты бальных танцев - «Венский вальс» (П. Кребс) и «Танго» (Ф. Кэмп) остаются традиционными в европейской программе и на современном этапе.

Ключевые слова: конкурсный бальный танец, Германия, учителя танцев, стандарт, латиноамериканская программа.

\section{Pavlyuk Tetjana, Candidate of Arts, Associate Kyiv National University culture and arts}

Formation of standard and Latin American programs in the competitive ballroom dance system in Germany

The purpose of the article is to identify the evolutionary features of the standard and Latin American programs of competitive ballroom dancing in Germany (1910-1970s); to determine the specifics of the transformational processes of professional activity of German dance teachers in the early twentieth century. in the context of the formation of a single dance style. Methodology. A systematic approach to the study of the specifics of the formation of the standard and Latin American competitive ballroom dance programs has been applied. To achieve the goal, complex research methods were used: historical and cultural (to consider the historical dynamics of the development of the dance teacher profession); historical and comparative (to study the process of forming a single dance style by representatives of England, France and Germany); typological (to identify factors influencing the development and canonization of competitive ballroom dance); system (to study the connections of the space of dance art); comparative (for comparing the structural elements of dances), as well as a method of theoretical generalization (for summarizing the study). Scientific novelty. For the first time in the history of Russian art criticism, the activities of the congress of the International Organization of Dance Teachers in Vienna (1911) were reviewed and analyzed, and the influence of German teachers on the formation of a single dance style in the competitive ballroom dance system was revealed. The curriculum approved by the Association of German Dance Teachers as an approbation of the decisions of the Vienna Congress is considered. The specifics of the formation of European and Latin American programs in the system of competitive ballroom dancing in Germany is investigated and the influence of German dancers on the development and canonization of new versions of ballroom dancing is revealed. Conclusions. Due to the intensification of the professional and organizational activities of dance teachers at the initiative of German dance groups in the early 1910s, a decision was made on the advisability of forming a unified dance style in the competitive ballroom dance system at the international level. A study of the features of regional competitions and national ballroom dance championships in Germany in the 1910-1970s. testifies to the specifics of the process of becoming the standard and Latin American programs in the country. Significant performances by French dancers had a significant impact on the popularization of Latin American dances in Germany. The variants of ballroom dances developed by German dancers - Vienna Waltz ( $P$. Krebs) and Tango ( $F$. Camp) remain traditional in the European program and at the present stage.

Key words: competitive ballroom dance, Germany, dance teachers, standard, Latin American program.

Актуальність теми дослідження. Культурний досвід, що зміг відобразити відчуття часу нової епохи, на початку XX ст. привніс інноваційний сенс в мистецтво бального танцю, а набутки минулих періодів вже здавалися недосконалими та застарілими. Розвиток конкурсної програми бальних танців на міжнародному рівні безпосередньо залежав від процесу стандартизації нових танців та відповідного рішення членів британської «Офіційної ради бальних танців» («Official Board of Ballroom Dance»). Натомість синопсис проведення регіональних змагань та національних чемпіонатів мали власну специфріку, дослідження та мистецтвознавчий аналіз якої зумовлений важливістю та необхідністю розширення наукової бази конкурсного бального танцю.

Мета статті - виявити особливості еволюціонування стандартної та латиноамериканської програми конкурсного бального танцю в Німеччині (1910-1970-ті рр.); визначити специфіку трансформа- 
ційних процесів професійної діяльності німецьких вчителів танців на початку XX ст. у контексті становлення єдиного танцювального стилю.

Аналіз досліджень засвідчує недостатню розробку проблематики формування стандартної та латиноамериканської програм в системі конкурсного бального танцю в Німеччині вітчизняними дослідниками. Зарубіжні науковці висвітлюють означене питання переважно в контексті дослідження розвитку певного конкурсного бального танцю (наприклад, Д. Гарібальді «Іноземне Танго. Міжнародна роль в створенні національного символу», 2010 р.; Х.-Дж. Шафер «Історія становлення танців»), визначення внеску провідних діячів стандартизації бального танцю (Б. Майєр-Каракіс «П.Дж. Річардсон - майстер адміністрації», «Ельза Уелс та міжнародний стиль») та ін.

Виклад основного матеріалу. Професія майстер танцю або танцмейстер у західноєвропейських країнах, внаслідок специфіки історичного розвитку тривалий час була безпосередньо пов'язана 3 суспільним життям та представництвом європейських судів, включаючи в себе організацію святкових балів. Завдання танцмейстера були різноманітними, не обмежувалися проведенням уроків танцю, передбачаючи організацію балів, навчання важливим соціальним (включно з уроками риторики) та спортивним навичкам (наприклад фехтування). Окрім того, майстри танцю працювали над створенням нових танців та навчальної літератури (танцювальні трактати) та ін. Провідні танцмейстери отримували фінансову та інституціональну підтримку для популяризації танців, а їх сфрера впливу базувалася на придворних структурах Європи. Відповідно уроки танців першочергово лишалися зарезервованими для представників аристократичних вищих класів, щоденних святкових вистав. Зауважимо, що тривалий час домінуючим на європейському паркеті був французький танець - кілька століть французькі майстри танцю працювали і в німецькомовних країнах. Професія громадського вчителя танців у Німеччині, який викладав переважно для міської буржуазії, з'явилася в середині XVIII ст. Розрив між збереженням придворних практик та громадських концепцій освіти, фрокусування на педагогічно орієнтованому навчанні танцювального мистецтва змінили концепцію професії «майстер танцю» на новаторську, якій набагато більше відповідала назва «вчитель танців».

Протягом XIX ст., з метою збільшення можливостей відвідувати уроки танців для представників буржуазії, було засновано багато шкіл танцю, друкувалися підручники та посібники для самоосвіти. Викладання бальних танців стало пріоритетним завданням вчителів танців. Відтоді ж визначення «бальні танці» використовувалося для того, щоб відрізнити даний вид танців від театральних та народних. Під цим терміном дослідники розуміють «обмежений спектр танцювальних фрорм буржуазії, що слідує чіткому регулюванню та керівництву професійних вчителів танців» $[7,102]$.

Проте можливість створення танцювальних шкіл або викладання без ліцензій нерідко використовувалися митцями чи студентами, які шукали заробіток. Механізми управління та регулювання танцювальним персоналом в системі танцювальної освіти були відсутні протягом тривалого часу.

На початку XX ст. у більшості європейських країн та США, з метою упорядкування процесу навчання бальним танцям, створювалися організації та асоціації вчителів танців. У 1908 р. у Берліні засновано Міжнародну асоціацію вчителів танцю та відбулися урочистості з нагоди першого Міжнародного дня вчителя танців, в якому брали участь 500 учителів з усього світу.

Проведення Конгресу 1911 р. у Відні під керівництвом Німеччини стало однією з найважливіших подій в історії Міжнародної організації вчителів танцю. Окрім представників п'яти німецьких асоціацій у конгресі брали участь вчителі танців зі Сполучених Штатів Америки, Англії, Угорщини, Австрії та Нідерландів [3, 70-72]. Для міжнародного співробітництва було створено Комітет міжнародної стандартизації танців, визначення єдиного танцювального стилю та оцінки уроків. Головною метою конгресу було затвердження єдиних універсальних танців. Американськими вчителями представлено танці «Ту степ» та «Бостон», а також пояснено послідовність кроків. Резолюції, які були опубліковані в друкованому органі організації, стали обов'язковими для всіх членів та делегатів Міжнародної федерації вчителів танців [2, 61]. Проведення наступного конгресу планувалося в 1915 р. у Гамбурзі. Проте через внутрішні протиріччя між німецькими та австрійськими асоціаціями, він не відбувся, а організація була розпущена у 1912 р.

Засідання Асоціації німецьких вчителів танців у Касселі (1911 р.), в якому брало участь 60 чоловік, було присвячено апробації результатів Віденського конгресу. На базі місцевої школи танців здійснено координацію репертуару. Відповідно до навчально-методичної програми в школі відводилося три години для вивчення класичного «Менуету», вісім - для вивчення «Кадрилі», вісім -для «Вальсу» та шість - для польських танців (викладач Д. Еберле). Викладання танців «Ту степ» та «Бостон» відбувалося за прийнятими у Відні методиками, проте на вивчення цих танців із загальної програми було виділено всього дві години (викладач з Гамбургу Х. Ф. Десін). Рубрика «Новий танець», до якої належали дані американські танці, на той час лишалася незначним явищем для німецьких вчителів. Подібне ігнорування, на нашу думку, свідчить про те, що подальший розвиток та популяризація нових для західноєвропейських країн танців, а також їх затвердження невдовзі в якості основних танців конкурсної програми змагань, лишалося на той час непередбачуваним.

В останньому номері видання ADTZ за 1911 р. повідомлялося про танцювальний конгрес Юждина Жиро в Парижі, в кому брали участь не лише фрранцузькі вчителі танців, а й їх іноземні колеги, переважно німці: «Великий Паризький конгрес вчителів танців, в якому брали участь всі фрранцузькі 
майстри танцю та велика кількість іноземних майстрів, завершився. Закони бального танцю були встановлені на новий сезон і відповідали рішенням, які німецькі вчителі танців схвалили під час нещодавніх обговорень екзотичних танців і танців зі складними рухами стегон» $[1,79]$.

Відповідно до специфіки розвитку системи конкурсних бальних танців у західноєвропейських країнах загалом, Німеччині зокрема, до 1930 р. традиційними на змаганнях були показові виступи модних танців. Наприклад, на першому чемпіонаті світу, який відбувся в Парижі у 1909 р., до програми ввійшли «Бостон», «Туркей Трот», «Регтайм», «Ванстеп» та «Грізлі Беар».

У Німеччині в програму стандартних танців у 1927 р. та 1928 р. було введено «Повільний вальс» («Англійський вальс») та «Повільний Фокстрот». 31932 р., до розподілу на стандартну та латиноамериканську програми, в якості додаткових до стандартних танців, конкурсантам пропонувалося виконати «Самбу» (музичний розмір - 2/4, 54 такти на хвилину, характеризується пружними діями на кожному кроці; виконується темпераментно та рухливо, з просуванням по колу; типові рухи та фрігури: «Боковий Самба-хід», «Бота-фрого», «Вольта», «Корта-джака», «Самба-баунс», «Самба-віск», «Самбахід» та ін.), спеціально розроблену в Європі для різноманітних танцювальних турнірів чи «Румбу».

На думку Е. Хадріх-Хорманн, неабиякий вплив на популяризацію латиноамериканських танців у Німеччині здійснили французькі танцюристи, зокрема подружжя Ронно з Парижу, які неодноразово демонстрували «Квадратну Румбу», «Самбо», «Пасодобль» та «Джиттербаг» в якості показових, а не конкурентних танців на різноманітних турнірах [8].

31950 р. в німецьких танцювальних турнірах серед професіоналів «Румба», а саме її американський варіант - «Квадратна Румба» (музичний розмір - 2/2, темп - 28-34 такти на хвилину; чотири чверті такти заповнюються кроками за ритмічною схемою «швидко-швидко-повільно»; характерним елементом $€$ «Кубинський рух» - покачування стегном під час перенесення ваги на робочу ногу; фрігуру - «Вигнутий поворіт партнерки», «Завертування», «Основний крок квадратної Румби», «Променадні брейки», «Просте колесо», «Сольні повороти») вважався шостим стандартним танцем.

У 1950-х рр. серед членів танцювальних організацій західноєвропейських країн велася дискусія - «Війна Румб», сутність якої полягала в прагненні британців замінити традиційну «Квадратну румбу» (американську, яку на європейському континенті популяризували французи, зокрема Л. Давід) на «Кубинську Румбу» (музичний розмір 4/4, темп помірний). Замість характерних американському варіанту більш простих фрігур та легкого ритму кроків, дана варіація, якій надавали перевагу британські вчителі танців, особливо П. Цурхер-Моргольє, відомий як месьє П'єр, вирізнялася надзвичайно складними елементами, позиціонуючись танцем балетного типу виконання. Як стверджує К. Вургаунер, у цьому конфлікті «Рейхська асоціація танцювального спорту» дотримувалася нейтралітету, а провідний німецький танцюрист П. Кребс підтримував фрранцузів [4, 79]. Після тривалих дебатів, британцям вдалося відстояти власну думку, відтак «Кубинська Румба» (типові рухи та фрігури: «Алемана», «Віяло», «Кукарача», «Нью-Йорк», «Основний рух Румби», «Правий поворот», «Розкриття», «Спотповорот» та ін.) була включена до латиноамериканської підгрупи танців міжнародної програми.

У контексті дослідження особливостей становлення європейської програми конкурсного бального танцю варто відмітити діяльність німецького чемпіона Пола Кребса, який посприяв розробці техніки виконання та канонізації нової версії «Віденського вальсу». У Німеччині цей танець, специфіка якого полягала не стільки в матеріалі фрігур, скільки в надзвичайних коливаннях тіла, був у програмі турнірів з 1932 р.

У 1950 р. танцювальна пара Пол Кребс та Маргіт Нігл, вигравши чемпіонат Німеччини, були помічені впливовим техніком бальних танців А. Муром (президентом «Міжнародної ради бальних танців») та запрошені провести спеціальну лекцію та майстер-клас із виконання «Віденського вальсу» в Лондоні, перед Британською танцювальною радою. У квітні 1951 р. «шістдесят вчителів та професійних танцюристів отримали значну користь від навчання Кребса, і деяким з них вперше вдалося правильно побудувати «флекерл» [11, 4]. Надаючи перевагу стилістичній свободі та логіці рухів, П. Кребс вбачав змістову частину танцю в зворотньо-хитаючій дії, яку пом'якшують фрігури та пози. Першочерговий темп вальсу складав 56 тактів на хвилину (Й. Штраус надавав перевагу 72-м), поступово набуваючи темпу 60-66, найбільш доцільним та встановленим як загальноприйнятий для проведення чемпіонатів. Характерною рисою версії танцю «Віденський вальс» П. Кребса стала відсутність варіацій та наявність лише шести рухів: «Правий поворот» («Натуральний поворот») та «Лівий поворот», - послідовність кроків, під час яких пара здійснює обертання праворуч або ліворуч відповідно; «Переміна вперед із лівого на правий» та «Переміна назад із правого на лівий» - послідовність кроків, що виконують 3 метою переміни вільної ноги або напрямку руху пари; «Правий Фрекерл» та «Лівий Фрекерл» - стрімкий та водночас плавний і розмірений поворот пари на місці, що виконується за один такт музичного супроводу [13].

З 1958 р. у Німеччині проводилися три типи турнірів: комбінований (з восьми танців - «Повільний вальс», «Танго», «Віденський вальс», «Повільний Фокстрот», «Квікстеп», «Румба», «Самба», «Пасадобль»); стандартний (п'ять танців - «Повільний вальс», «Танго», «Віденський вальс», «Повільний Фокстрот», «Квікстеп»); латиноамериканський (чотири танці - «Румба», «Самба», «Пасадобль», «Танго») [6, 10]. Провідними німецькими танцювальними парами 1950-1960-х рр. були Пол Кребс та Маргіт 
Нігл, Хайнц-Георг та Гудрун Фінк, Герд і Трауте Хадріх, Детлеф Хегман та Урсула Кеммерер, Карл та Урсула Бреуер, Юрген та Хелена Бернхол [6, 36-38].

Єдиним танцем, представленим у всіх типах турнірів було «Танго», що пояснювалося тривалою невизначеністю його приналежності. У контексті даного дослідження вважаємо за доцільне більш детально проаналізувати процес становлення «Танго» в програмі європейського стандарту.

Приблизно з 1910-1912рр. аргентинське танго стало відоме в Парижі як перший південноамериканський танець, який одразу приєднали до «нових танців». На відміну від «Регтайму» «Танго» вирізнялося набагато повільнішою танцювальною музикою та хореографією, провокуючи відповідно більш тісний фізичний контакт і відмінне від інших танців повноцінне занурення у сприйняття.

Специфіка так званої «тангоманії» у контексті особливостей розвитку бальних танців у Франції характеризується посиленням соціальної значимості танцювальних практик. Проте на відміну від великої кількості нових танців, що були успішними на сценах великих міст, популярність в танцювальних залах та включення невдовзі до списку конкурсного бального танцю вирізняло «Танго» від багатьох недовготривалих модних танців у Франції початку XX ст.

«Танго», що популяризувалося в Парижі, хоча й було імпортовано безпосередньо з аргентинських першоджерел, все ж лише незначною мірою відносилося до аргентинського танцю технічно та стилістично. М. Рівера, вчитель танців та автор кількох важливих теоретичних танцювальних трактатів, у передмові до «Le tango et les danses nouvelles» [12] стверджував, що новий танець стилізовано в абсолютно нове «Танго». Хореографія танцю була радикально змінена, щоб посилити ефектність, екстравагантність та екзотичність - оригінальний варіант стилізовано витонченими, практично балетними позами (витягнуті руки, тулуб та шия) і грубими, схожими на фігури танцю «Апача» глибокими провалами, вигинами назад, карколомними коливаннями та ін. У новому, «французькому варіанті», було поєднано повітряну елегантність з елементами приземленості, що створювало ефект чуттєвості та пристрасті.

Зазначимо, що на відміну від паризького вищого товариства, які в більшості прийняли екзотичний танець ще у 1910-1920-х рр., пануючі верхівки інших європейських країн тривалий час виступали проти популяризації «Танго». Наприклад, під час Першої світової війни німецький кайзер Вільгельм II видав указ, відповідно до якого будь-який німецький офіцер, якого побачать танцюючим «Танго» у військовій формі, буде засуджений військовим трибуналом [5, 82]. До Великобританії, на спеціально організовані для членів вищого товариства «чаї», запрошувалися вчителі танцю з Парижу, щоб навчити молодих жінок «танцювати пристойне «Танго» [10, 96]. Натомість у 1920-х рр. британці вже затвердили навчальну програму для танцю «Танго» на основі довоєнного французького варіанту.

Безпосередню залежність процесу популяризації бальних танців у Німеччині від діяльності окремих танцюристів та редакторів танцювальних журналів засвідчує приклад Франца Вольфрганга Коебнера - головний редактор спеціалізованого періодичного видання «Елегантний світ» здійснив величезний внесок в процес популяризації «Танго» в Берліні $[9,150]$.

Протягом 1930-х рр. у Німеччині «Танго» зазнає подальших стилістичних трансформацій (адаптовано хореографрію та музичний супровід) - танцюристом-аматором Ф. Кемпом було розроблено та популяризовано варіант, нині відомий як бальне «Танго» $[5,88]$. У 1961 р., за пропозицією британських вчителів танців, оголошено, що «Танго» повинно належати до п'ятірки стандартних танців.

У 1959 р. у Лондоні відбувся перший офіційний чемпіонат світу серед професіоналів з латиноамериканських танців. Вже за рік у Німеччині було проведено перший чемпіонат країни з латиноамериканських танців серед аматорів «Федеральна кваліфікація» («Bundesqualifikation»), переможцями якого стала відома танцювальна пара Карл Брейєр та Урсула Брейєр. Танцюристи неодноразово здобували перемогу в стандартній програмі, на національному та міжнародному рівні - двічі чемпіони світу, двічі чемпіони Європи, багаторазові чемпіони Німеччини. У програму латиноамериканських турнірів офріційно включено танці «Самба» та «Пасадобль».

Перший німецький чемпіонат латиноамериканських танців серед професіоналів - «Федеральна кваліфікація», який виграла пара Р. Траутц та І. Шміт відбувся у 1960 р. У 1961 р. четвертим латиноамериканським танцем програми змагань німецьких турнірів визнано «Ча-ча-ча». «Джайв» було офріційно введено до латиноамериканської програми змагань серед професіоналів як п'ятий танець у 1968 р., а серед аматорів лише у 1973 р.

Таким чином, процес стандартизації конкурсної європейської та латиноамериканської програм бального танцю в Німеччині, що тривав понад 60-т років (з 1911 р.) було завершено.

Наукова новизна. Вперше в історії вітчизняного мистецтвознавства розглянуто та проаналізовано діяльність конгресу Міжнародної організації вчителів танців у Відні (1911р.) та виявлено вплив німецьких вчителів на формування єдиного танцювального стилю в системі конкурсного бального танцю. Розглянуто навчальну програму затверджену Асоціацією німецьких вчителів танців в якості апробації рішень Віденського конгресу. Досліджено специфіку формування європейської та латиноамериканської програм в системі конкурсного бального танцю в Німеччині та виявлено вплив німецьких танцюристів на розробку і канонізацію нових версій бальних танців.

Висновки. Внаслідок активізації профресійної та організаційної діяльності вчителів танців за ініціативи німецьких танцювальних об'єднань на початку 1910-х рр., було затверджено рішення про до- 
цільність формування єдиного танцювального стилю в системі конкурсного бального танцю на міжнародному рівні. Дослідження особливостей проведення регіональних змагань та національних чемпіонатів бальних танців у Німеччині в 1910-1970-ті рр. засвідчує специфіку процесу становлення в країні стандартної та латиноамериканської програм. Значний вплив на популяризацію в Німеччині латиноамериканських танців мали показові виступи французьких танцюристів. Розроблені німецькими танцюристами варіанти бальних танців - «Віденський вальс» (П. Кребс) та «Танго» (Ф. Кемп) лишаються традиційними в європейській програмі й на сучасному етапі.

\section{תimepamypa}

1. Aus aller Welt. Die neuen Gesetze des Ballsaals. ADTZ. Nr. 12 (1911). S. 79-80.

2. Bericht uber den 2. Internationalen Tanzlehrer-Kongreb in Wien am 16. Bis 19. Juli 1911. ADTZ. Nr. 10 (1911). S. 61.

3. Bericht uber den 2. Internationalen Tanzlehrer-Kongreb in Wien am 16. Bis 19. Juli 1911. ADTZ. Nr. 11 (1911). S. 70-72.

4. Burgauner Ch. 75 Jahre Deutscher Tanzsportverband Zwischenbilanz auf dem Weg ins 21. Jahrhundert. Tanzspiegel. 2006. № 6. pp. 71-90.

5. Denniston Ch. The Meaning of Tango: The Story of the Argentinian Dance. London: Portico, 2007. 224 p.

6. Die Turniertänze. Tanzsport $\quad$ Info $\quad$ Service. 2018. https://www.tanzsport.de/files/tanzsport/downloads/presse/dtv-pressemappe.pdf.

7. Fink M. Der Ball: Eine Kulturgeschichte Des Gesellschaftstanzes Im 18. Und 19. Jahrhundert. Studien Verlag, 1996. 237 p.

8. Hädrich-Hörmann E. The German Belief. 2014. URL : https://wdced.com/2014/11/the-german-belief/ (дата звернення 15.07.2019).

9. Lange K. Tango in Paris und Berlin: eine transnationale Geschichte der Metropolenkultur um 1900. Vandenhoeck \& Ruprecht, 2015. 214 p.

10. Lindholm Ch. Culture and Authenticity. Malden: Blackwell Publishing, 2008. 176 p.

11. Moore A. Ballroom Notes. The Dancing Times. 1951. April. London : The Dancing Times. p. 4.

12. Rivera M. Le tango et les danses nouvelles. Paris, $1913.91 \mathrm{p}$.

13. Swain M. Perfect 10: The Viennese waltz. 2012. URL : http://archives.dance/2012/11/29/perfect-10-theviennese-waltz-by-marianka-swain/ (дата звернення 14.07.2019).

\section{References}

1. Aus aller Welt. Die neuen Gesetze des Ballsaals. ADTZ. Nr. 12 (1911). pp. 79-80. [in German].

2. Bericht uber den 2. Internationalen Tanzlehrer-Kongreb in Wien am 16. Bis 19. Juli 1911. ADTZ. Nr. 10 (1911). p. 61 [in German].

3. Bericht uber den 2. Internationalen Tanzlehrer-Kongreb in Wien am 16. Bis 19. Juli 1911. ADTZ. Nr. 11 (1911). pp. 70-72 . [in German].

4. Burgauner, Ch. (2006). 75 Jahre Deutscher Tanzsportverband Zwischenbilanz auf dem Weg ins 21. Jahrhundert. Tanzspiegel, no. 6, pp. 71-90. [in German]. English].

5. Denniston, Ch. (2007). The Meaning of Tango: The Story of the Argentinian Dance. London: Portico. [in

$\begin{array}{ccccc}\text { 6. Die } & \text { Turniertänze. } & \text { Tanzsport } & \text { Info } & \text { Service. } \\ \text { https://www.tanzsport.de/files/tanzsport/downloads/presse/dtv-pressemappe.pdf. p. 10. } & \text { [in German]. }\end{array}$

7. Fink, M. (1996). Der Ball: Eine Kulturgeschichte Des Gesellschaftstanzes Im 18. Und 19. Jahrhundert. Studien Verlag. [in German].

8. Hädrich-Hörmann, E. (2014). The German Belief. URL : https://wdced.com/2014/11/the-german-belief/ [in

9. Lange, K. (2015). Tango in Paris und Berlin: eine transnationale Geschichte der Metropolenkultur um 1900. Vandenhoeck \& Ruprecht. [in German].

10. Lindholm, Ch. (2008). Culture and Authenticity. Malden: Blackwell Publishing. [in English].

lish].

11. Moore, A. (1951). Ballroom Notes. The Dancing Times. 1951. April. London : The Dancing Times. [in Eng-

12. Rivera, M. (1913). Le tango et les danses nouvelles. Paris. [in French].

13. Swain, M. (2012). Perfect 10: The Viennese waltz. URL : http://archives.dance/2012/11/29/perfect-10-theviennese-waltz-by-marianka-swain/ [in English]. 